\title{
Hepatotoxicity of Pyrrolizidine Alkaloids
}

\author{
Manuela G. Neuman ${ }^{1,2}$, Lawrence B. Cohen ${ }^{3,4}$, Mihai Opris ${ }^{1}$, Radu Nanau ${ }^{1}$, Hyunjin Jeong ${ }^{1,2}$ \\ ${ }^{1}$ In Vitro Drug Safety and Biotechnology, ${ }^{2 \cdot}$ Department of Pharmacology and Toxicology, ${ }^{3 .}$ University of Toronto, Division \\ of Gastroenterology, Sunnybrook Health Sciences Centre, ${ }^{4}$ Department of Internal Medicine, University of Toronto, Toronto, \\ Canada.
}

Received, August 19, 2015; Revised, September 19, 2015; Accepted, November 21, 2015; Published, November 23, 2015.

\begin{abstract}
PURPOSE: This article aimed 1) to review herbal medicine containing pyrrolizidine alkaloids (PA)-induced toxicities of the liver; 2) to encourage the recognition and prevention of common problems encountered when using complementary and alternative medicine and 3) to review the toxic effects of herbal remedies containing PAs. DESIGN AND METHODS: We performed a systematic literature search using the PubMed and Google Scholar engines. The search was not restricted to languages. We also provide an interpretation of the data. CONCLUSIONS: Herbal remedies containing PAs can induce liver damage, including hepato- sinusoidal obstruction syndrome or veno-occlusive disease. Preventing overdose and monitoring long-term use of such remedies may avoid glutathione depletion leading to mitochondrial injury, and therefore avoid liver cell damage. Moreover, immediately stopping the herbal medication prevents further harm to the liver. Chronic consumption of hepatotoxicants can lead to cancer formation and promotion. The role of active metabolites in PA-induced liver toxicity and their mechanism of action require further investigation.
\end{abstract}

This article is open to POST-PUBLICATION REVIEW. Registered readers (see "For Readers") may comment by clicking on ABSTRACT on the issue's contents page.

\section{INTRODUCTION}

Therapies consisting of complementary and alternative medicine (CAM) span a diverse group of substances that include herbal and dietary supplements (1). The use of CAM therapies increased dramatically in the last 20 years. MacLennan et al. (2) described the escalating use of CAM in Australia. In the United States, $65 \%$ of the population reported the use of CAM therapies (3-5). The out-of-pocket cost of purchasing nonvitamin, non-mineral natural products amounted to $\$ 14.8$ billion in 2007 in the United States (6).

Herbal supplements can be associated with toxicities $(7,8)$. The frequency of hepatotoxicity attributable to plant-derived products is underreported, since not all patients inform their clinicians that they use such therapies (9). As a result, hepatotoxicity associated with herbal use may be missed (10-13).

Indirect hepatotoxicants, as defined by Zimmerman (14), are substances that cause hepatic injury by producing selective biochemical or physiologic lesions which disrupt metabolic pathways or processes essential for the maintenance of parenchymal cell integrity. This is in contrast to direct hepatotoxins, which are agents that produce cholestasis, interfering mainly with biliary secretion, and usually sparing the parenchyma. Indirect hepatotoxicants include agents that disturb or competitively inhibit essential metabolites, alkylate or arylate key molecules, alter membranes, or produce other selective metabolic blocks and physiologic lesions. Senecio extract, a natural hepatotoxin, appears to fit this category in the experimental setting $(15,16)$.

Traditional medicines composed of herbs often contain a complex mixture of both beneficial and toxic phytochemicals. These are directly prepared from raw materials with little to no separation procedures. Acute poisoning due to the use of traditional medicines is a serious problem in South Africa. The inappropriate use of medicinal herbs has resulted in numerous fatalities, especially in young children $(7,17-23)$.

Corresponding Author: M.G. Neuman M.Sc., Ph.D., FACB IN VITRO DRUG SAFETY \& BIOTECHNOLOGY, Banting Institute, 100 College Street, lab 217 Toronto, Ontario, Canada, E-mail: manuela.neuman@utoronto.ca 
It is currently estimated that $80 \%$ of the South African population consults with traditional healers and uses some form of traditional herbal medicine, usually in combinations $(24,25)$.

This review deals with phytochemicals of the cytotoxic group that are of special interest as classical, experimental hepatotoxicants, or as agents of importance to clinical medicine. The natural toxins discussed in this paper are excellent models of indirect hepatotoxicity. They include a number of agents of practical importance to human and veterinary medicine such as the pyrrolizidine alkaloids (PA) (16). PAs are well-studied hepatotoxins that produce selective biochemical lesions.

In figure $1 \mathrm{a}$ (Senecio doronicum) and figure $1 \mathrm{~b}$ (Senecio jacobea) we illustrate two of the species of Senecio. The experimental hepatocytoxicity induced by natural substances has been described by several authors $(15,26)$.

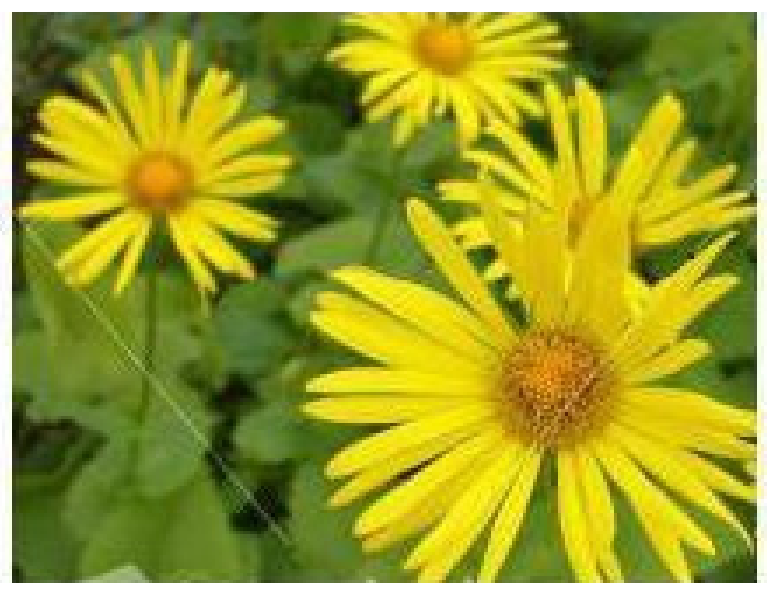

Figure 1a Senecio doronicum

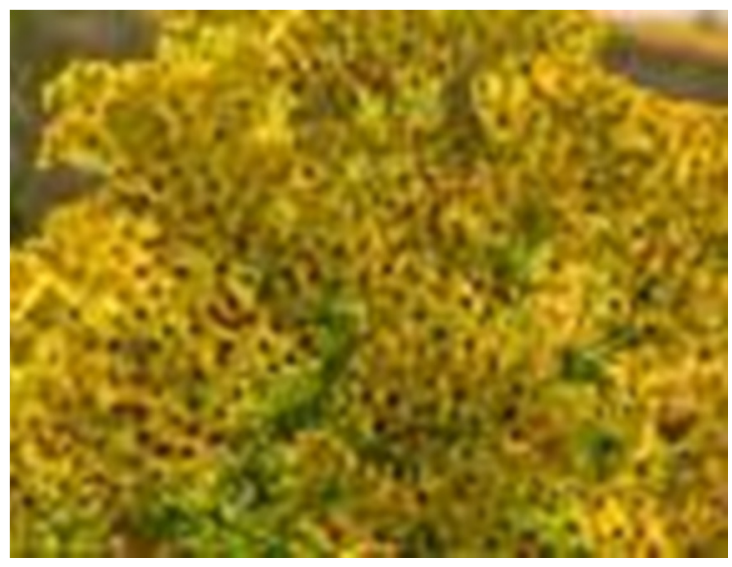

Figure 1b Senecio jacobea

\section{Pyrrolizidine alkaloids}

PAs are a class of alkaloids based on the structure of pyrrolizidine which are present in distinct plant families that grow worldwide $(15,16,27)$ (Table 1.). PAs and PA N-oxides have been identified in plant species throughout the world (3\% of the world's flowering plants) (28). PA hepatotoxicity, which has been long recognized, is predominantly observed after exposure to the following plant families: Boraginaceae (Heliotropium sp., Trichodesma sp., Symphytum sp. [Comfrey]), Compositae (Senecio sp. [Bush Teas], Eupatorium sp), Crotalaria sp. (Leguminosae), Greater Celandine (Chelidonium majus), and Ariaceae (Castilleja sp.) (28-48). Kavakava (Piper methysticum) contains kava pyridone alkaloid, pipermethystine, which is abundant in leaves and stem peelings. This alkaloid induces mitochondrial toxicity. In addition, kavalactones such as 7,8- dihydromethysticin and desmethoxyangonin, abundant in the roots of the plant, may lead to different organ toxicities (46).

While sporadic in Western countries, PA poisoning is nearly endemic in areas where traditional remedies are frequently used, such as China (40), Africa and India (49-52). The toxicity of Senecio plants and related species has been shown to cause disease in grazing domestic animals. A series of studies has been reviewed by McLean (53). The toxic principles (PAs) have been identified, their presence in some plants has been established, and the characteristics of the hepatic injury they produce has been defined (53). The hepatotoxic and carcinogenic species of plant pyrrolizidine alkaloids (e.g. echimidine and jacobine), are generated by hepatic CYP2B6 and CYP3A4. Figure 2a presents precursors of pyrrole metabolites The acute hepatic injury produced by PAs includes zone 3 hepatic necrosis, minor steatosis, and occlusive injury of the small branches of the efferent venules $(10,53,54)$. Chronic expoxure leads to the development of very large cells ("megalocytes"), cirrhosis and hepatocellular carcinoma (53). The mechanism of injury appears to involve the injury of the hepatic vasculature and parenchyma by pyrrole derivatives that react with DNA (55-57).

All PAs contain the core structure of pyrrolizidine, which consists of two fused pentarings with a nitrogen atom at position four, one of the two points of fusion. The hepatotoxic derivatives are esters of 1-hydroxymethyl-1,2-dehydro-7-hydroxypyrrolizidine. Requirements for toxicity appear to include the 1-2 unsaturation and the esterification 
with a branched-chain acid (53). These 1-2unsaturated PAs are metabolized by CYP450 enzymes in the liver to the corresponding "pyrrole type esters", responsible for PA-induced toxicity. Saturation of the double bond eliminates the toxicity; esterification does not play a major role in toxicity. Solubility of the alkaloids in aqueous solvents is low at a neutral $\mathrm{pH}$, and is enhanced by acidification (53, 58). Pyrrolizidine alkaloids consist of a necine base and necic acid. The necic acids are four to six carboncontaining mono- or di-carboxylic acids. The structures of the four representative types are necine bases, platynecine, retronecine, heliotridine, and otonecine. The platynecine type PAs, which do not contain a double bond in the necine base, are considered weakly toxic. However, the retronecine-, heliotridine-, and otonecine-type that have a doublebond at the $\mathrm{C} 1$ and $\mathrm{C} 2$ positions of the necine base exhibit high levels of hepatocytotoxicity (10).

\section{Laboratory measurements}

Both acute and chronic PA-induced toxicity have been reported in humans depending on the quantity and frequency of the exposure (59). Urine and blood samples belonging to patients who have been exposed to traditional medicine can be used to identify the quantity of PA that is present, which can help monitor chronic or acute PA toxicity. Steenkamp et al. (60) and Neuman and Steenkamp (51) showed an increased risk of venoocclusive disease in people who used herbal remedies containing PAs, despite no previous medical history. In addition, no herb-therapeutic or herb-herb interaction was noted, since the patients did not take any barbituates, benzodiazepines, tricylic antidepressants, paracetamol, or other herbal remedies. Moreover, there are several reports of using the herbal material to livestock. Senecio oxyriifolius $D C$ is given to animals with swelling and Senecio tamoides $D C$ is administered to animals with anthrax (61).

Analytical chemistry techniques such as highperformance liquid chromatography (HPLC), gas chromatography (GC), mass spectroscopy (MS), and thin layer chromatography (TLC), in tandem with each other, have been conducted by past researchers to provide chemical identification and quantitative data regarding the amount of PAs present in blood and urine (22, 62-68). Although analytical techniques such as liquid chromatography (LC) and GC are currently available to detect traces of PAs, there are no rapid screening assays to assess levels of PAs on a commercial scale to be adopted in the food regulation industry. However, commercial scale analytical methods are being explored as a way to sensitively detect toxic PAs from complex mixtures. The lack of reference standards for analysis is a great hindrance for screening methods to be implemented (69). Oplatowska et al. are in the process of developing a rapid enzyme-linked immunosorbent assay (ELISA) capable of performing a multiplex immunoassay for PAs with N-oxide (70). Griffin et al. are also investigating a LC-ion trap MS method on a commercial scale to detect PAs in honey (71), whereas Martinello et al. are finding quantitative methods to measure PA content by UPLC-MS to extrapolate on an industrial level (72).

\section{Pyrrolizidine alkaloids toxicity}

PAs are found in more than 6,000 plants within the Asteraceae, Boraginaceae, Compositae, and Fabaceae families $(28,73-75)$. In total, over 300 different PAs have been identified, and they are categorized according to their necine base and necic acid components $(76,77)$. Plants that are part of the Senecio genus are reported to have high amounts of PAs in the form of senecionine, retrorsine, riddeliine, integerrimine, neosenkirkine, and florosenine $(27,78)$. Not all PAs are toxic. However, the ones that are reported to be toxic all commonly have a double bond in the ring nucleus, an esterified hydroxyl group, and a branched carbon in at least one of the ester side chains $(76,77,79)$. Senecionine, retrorsine, and riddelliine are three of many PAs that meet these criteria. Despite their high content in toxic PAs, plants of the Senecio spp. are commonly used in traditional medicine for numerous purposes. PA-induced toxicity manifests its problematic nature in two dimensions: firstly, grazing livestock experience irreversible and fatal liver damage by feeding off plants that are rich in PA or feeds that are contaminated with plants rich in PA; and secondly, individuals treated with traditional medicine or exposed to contaminated food, including both contaminated plants and products from infected animals, may experience toxicity.

Senecio-induced liver injury is a commonly reported issue for livestock. Countries such as Zimbabwe (80), South Africa (81), the United Kingdom (82), Belgium (83), France (84), Australia (85), Spain (86), Brazil (87-91), Canada (92), and the United States $(93,94)$ have all reported PA- 
induced livestock deaths after post-mortem investigation. Senecio-induced liver poisoning in animals is preventable, and represents a high cost for farmers. Approximately $10 \%$ of cattle and 5\% of small livestock are poisoned by PA-rich plants annually in South Africa, which is equivalent to approximately 8,107,521 South African rand in financial cost per year (81). Stuart et al. (95) reported Cocklerbur (Xanthium strumarium) intoxication in swine, while Witte et al. (96) describe the same phenomenon in cattle. Ninety per cent of the complaints received by the United Kingdom Department for Environment, Fisheries and Rural Affairs are from farmers regarding weed catastrophes such as Senecio (97). The Australian dairy industry loses $\$ 2,428,211$ per year in milk production and $\$ 434,327$ per year in beef production because of Senecio jacobaea. Overall, more than $\$ 4.0$ million is lost in the Australian agricultural industry solely due to Senecio jacobaea (98). The United States Department of Agriculture have reported that cattle, deer, horses, and goats are exposed to plant toxins by accidental exposure or dried as part of silage or hay $(99,100)$. It thus provided suggested techniques to help mitigate the problem such as crop rotation techniques, proper forage harvesting, and control of weed invasion by pulling weeds mechanically or using broadleaf herbicide to mitigate the harm of PArich plants on livestock viability (100). Nevertheless, both developed and developing countries that face PA-induced livestock death lack detailed agricultural protocols that would assist farmers from livestock attrition. Basic science research must be communicated coherently and detailed protocols must be implemented for farmers and land managers in order to improve agricultural conditions.

Medicinal tea containing PA-rich herbs also induced serious liver veno-occlusive disease in many parts of the world, with numerous people ending up with severe liver damage and death (31, 34, 101-103). Although analytical methods have confirmed that numerous herbal teas contain PAs, which is detrimental to health, there are still licensed and registered commercial products that are available in the market for consumers to purchase (104). For example, comfrey has been removed from the market in France following numerous reports of liver damage. It remains widely available in the United States despite the US Food and Drug Administration's requests to remove comfrey products from the market (105).

Special populations are more vulnerable to products containing PAs. Many of PA containing herbal teas are marketed for pregnant or lactating mothers; traces of PA may be exposed to infants, harming the mother's child (106). Another source of exposure to PA is from food contamination. Honey from nectar of PA-rich flowers is often contaminated with PAs according to LC-MS results, and the presence of PAs in honey is not uncommon (107-113). Milk could also contain traces of PAs if the cows eat Senecio-contaminated feed (114). An outbreak of hepatic veno-occlusive disease (VOD) in Western Afghanistan occurred after people were exposed to PA-contaminated wheat flour (115).

A cohort study on Ugandan participants showed an increased risk of liver fibrosis when an individual uses traditional medicine composed of herbs from the Asteraceae, Fabaceae, and Lamiaceae families (116). This is problematic since many Ugandan patients with human immunodeficiency virus resort to traditional medicine and neglect their antiretroviral therapy, which may potentiate non-compliance to their prescribed treatment and by itself, or in combination with alcohol, may lead to hepatotoxicity $(52,117)$.

Zimmerman (10) emphasized that the rules for "causality assessment" in attributing liver injury to any toxin are similar to those for other therapeutics (e.g. exposure must lead to the onset of liver injury and other liver diseases should be excluded). The severity of liver injury is enhanced by repeated exposure. The mainstay of therapy for herbal hepatotoxicity is withdrawal of the offending toxin. Liver injury may improve after stopping the ingestion of the toxin. However, in fulminant cases, an abrupt decline in liver biochemical tests may indicate worsening of the liver status rather than improvement of its functional capacity. As a consequence, early recognition of toxicity is important to permit assessment of severity and monitoring for acute liver failure (118). More extensive disease can lead to cirrhosis, hepatic failure, and death (14). The acute form is rapidly fatal in 20 to 40 percent of patients (with worse prognosis in adults compared with children). Approximately $15 \%$ of patients with acute disease will progress to subacute or chronic injury, succumbing within several years to end stage liver disease. Some of the patients develop cirrhosis and portal hypertension (14).

Regardless of the intended use of traditional 
remedy, clinical case reports have been published regarding PA-induced hepatotoxicity; thus, the toxicology behind Senecio spp. and other PA-rich herbs should not be neglected or undermined. Moreover, monitoring the levels of PA in blood and/or urine will help in diagnosing and treating the toxic reaction.

\section{Hepatic sinusoidal obstruction syndrome}

Numerous case reports in human and veterinary medicine indicate that PAs at high doses induce sinusoidal obstruction syndrome (HSOS) previously referred to as hepatic veno-occlusive disease (VOD). Without medical intervention and discontinuation of the toxicant exposure, HSOS can lead to more severe complications such as liver fibrosis, cirrhosis, necrosis, and ultimately death (119). Willmot and Robertson first clinically described the symptoms of HSOS by ascites, hyperbilirubinemia, hepatomegaly, and abdominal pain (119-121). Nonthrombotic luminal occlusion of the small centrilobular veins leads to hepatic congestion and subsequent hemorrhagic parenchymal necrosis (10). More extensive disease can lead to hepatic failure, and death (10). Regardless of the cause, HSOS begins with injury to the hepatic venous endothelium. The preexisting liver disease increases the risk of developing HSOS. Preexisting liver disease may impair metabolism of drugs and phytochemicals, and thus predispose to cell injury. In addition, patients with chronic viral or alcoholic hepatitis may have abnormalities in hepatic endothelial cells that could make them more susceptible to PAs (15). Endothelial cells in patients with hepatitis may abnormally express adhesion molecules and procoagulant factors. The acute form is rapidly fatal in 20 to 40 percent of patients (with worse prognosis in adults compared with children). Approximately 15 percent with acute disease will progress to subacute or chronic injury, succumbing within several years to end stage liver disease (10). Early pathologic changes include the deposition of fibrinogen and factor VIII within the venular walls and liver sinusoids (10).

HSOS is also a serious complication that is not uncommon for hematopoietic stem cell transplant patients and exhibit similar pathological features (121). The pathogenesis of HSOS is elucidated employing in vivo and in vitro studies to understand its molecular basis. Studies suggest that endothelial cell injury via oxidative stress and PA-induced apoptosis of hepatocytes is one contributing factor.
In vivo and in vitro models show concentrationdependent PA-induced depletion of glutathione indicative of oxidative stress by PAs (122). One proposed mechanism implicates PAs in inhibiting hepatocyte proliferation and inducing cell death is by decreasing the level of Bcl-x, an anti-apoptotic protein, and increasing the level of Bax, a proapoptotic protein that enhances the release of cytochrome $\mathrm{c}$ from the mitochondria for apoptosis (123). Another proposed mechanism to explain PAinduced apoptosis involves reduced $\mathrm{p} 53$ expression, which is independent from Bcl expression (124). Zuckerman et al. have conducted an in vitro study and demonstrated that toxic PAs not only induce apoptosis, but also clump the tubulin cytoskeleton at relatively low concentration, and lead to necrotic cell bodies (125). The inflammatory response is also suggested to be part of the pathogenesis of PAinduced HSOS (16). Cytokines such as tumor necrosis factor (TNF)- $\alpha$, interleukin (IL)- $1 \beta$, and endothelin-I (ET-1) are secreted by monocytes in response to PAs $(50,126)$. TNF- $\alpha$ is a cytokine that directly induces cell death in normal endothelial cells (127). The pro-coagulant properties of TNF- $\alpha$ and IL-1 $\beta$ and the coagulation pathway remain active areas of research in understanding HSOS $(128,129)$.

As a result of liver injury, bile acid homeostasis is also compromised. Xiong et al. have investigated PA-induced hepatotoxicity and its change in metabolomics and genomic profiles in hepatocytes (130). Genome microarray analysis and quantitative polymerase chain reaction (qPCR) were used to observe and verify the down-regulation of key enzymes associated with bile acid homeostasis such as CYP7A1, bile acid CoA-amino acid $N$ acetyltransferase, sodium taurocholate cotransporting polypeptide, and organic anion transporting polypeptide, and the up-regulation of multidrug-resistance-associated protein 3. Patient serum metabolomic analysis via ultraperformance liquid chromatography (UPLC) showed an elevated activity of alanine aminotransferase, aspartate aminotransferase, and increased concentration of total bilirubin, all indicative biomarkers to hyperbilirubinemia associated with HSOS. A murine model conducted by Xiong et al. showed similar results, with elevated level of alanine aminotransferase, aspartate aminotransferase, and total bilirubin concentration, all indicative biomarkers of hepatotoxicity (131).

PAs undergo three main metabolic pathways. PAs that are hydrolyzed to a carboxylic acid or N- 
oxidized to a N-oxide metabolite are non-toxic and soluble in water and thus excreted via urine (53). Although PAs in their native form are non-toxic, when they are biotransformed by CYP3A their metabolite reacts with nucleic acids and proteins (132-135). The initial oxidation by CYP3A, then the spontaneous dehydrogenation of the necine ring produces a dehydro-pyrrolizidine compound, a toxic pyrrolic ester that acts as an electrophile. Thus, CYP3A inducers could increase the susceptibility of PA-induced toxicity, while CYP3A inhibitors could prevent toxic outcomes (136), since inhibitors yield less dehydropyrrolizidine alkaloids (137). Although pyrrolizidine $\mathrm{N}$ - oxide metabolites are generally non-reactive and get excreted via urine, excess of these metabolites can be further biotransformed into toxic epoxides and necine bases, which is detrimental to cellular function (138). At low concentrations, endogenous detoxification systems, notably glutathione, would conjugate the electrophilic metabolite, stabilizing it for excretion via urine. In vivo and in vitro studies have shown that PA-induced HSOS has been linked to the depletion of glutathione in sinusoidal endothelial cells, indicative of PA-induced oxidative stress (122). Cattle with irreversible liver damage induced by Senecio spp. showed higher activity of copper-zinc superoxide dismutase and thiobarbituric acid-reactive substances, and higher level of nonprotein sulfhydryl group, all indicative of lipid peroxidation and oxidative stress as contributing pathological pathways (59). Glucuronidation of PA has yet to be extensively investigated but the study by $\mathrm{He}$ et al. showed that senecionine and other PAs are conjugated by glucuronic acid in humans and animals (139).

\section{PA toxicity is dose- and time-dependent}

HepG2 cells have shown senecionine-induced doseand time-dependent cytotoxicity assessed by MTT, bromodeoxyuridine incorporation assay, neutral red uptake assay, resazurine assay, lactate dehydrogenase release assay, and sulforhodamine $\mathrm{B}$ assay $(16,140)$. Moreover, cell lines and injection bioassays show that PAs are cytotoxic in a dose-dependent manner (141). L-02 cells show in a dose- and time-dependent manner that senecionine and other PAs such as adonifoline, senecionine, monocortaline, and isoline deplete cellular glutathione levels and increase the level of oxidized glutathione, resulting in a decreased ratio of glutathione to oxidized glutathione $(122,141)$.
$\mathrm{N}$-acetyl-cysteine, the precursor to glutathione, an antioxidant compounds, lowered the susceptibility of PA-induced hepatotoxicity $(122,143)$, while a glutathione synthesis inhibitor increased the susceptibility to PA-induced hepatotoxicity (143). Primary mice hepatocytes have shown that senecionine and other PAs induce apoptotic DNA laddering, caspase-3 activation, and a decreased level of Bcl-xL, an anti-apoptotic protein (144), thus concluding that PAs share a common hepatotoxic signaling pathway that involves the degradation of Bcl-xL protein and activation of the intrinsic apoptotic pathway, mediated by the mitochondria.

Our previous research regarding Senecioinduced toxicity has showed that an aqueous extract of Senecio induced cytotoxicity in a dosetime-dependent manner, as determined by ELISA and terminal dUTP nick-end labeling in HepG2 cells. Furthermore, glutathione depletion was observed when cells were treated with Senecio extract and $\mathrm{N}$-acetyl-cysteine was shown to potentially reduce cytotoxicity induced by Senecio. Lastly, caspase-3 and caspase-9 inhibitors were demonstrated to prevent apoptosis associated with aqueous Senecio extract (145). A proposed mechanism of toxicity is illustrated in Figure $2 \mathrm{~b}$.

In hepatocytes, CYP - P450s convert dehydropyrrolizidine alkaloides (PA)s to 6,7-dehydropyrrolizine esters which represent the toxic metabolites. Dehydro-retronecine and dehydroheliotridine are produced from the initial toxic metabolites via reactive oxygen species. Esterases can detoxify dehydro-PAs by hydrolyzing their ester groups to produce non-toxic necic acids and necines. Dehydroretronecine and dehydroheliotridine react rapidly with nucleophiles such as $\mathrm{SH}, \mathrm{OH}, \mathrm{NH}$ groups on nucleotides, as well as with proteins to form adducts. Glutathione is responsible for detoxification of the toxic metabolites in the liver. Endothelial cells lining the sinusoids of the liver became damaged due to an accumulation of toxic metabolites. This phenomenon causes the obstruction of the sinusoids.

Over time, some tissue-bound adducts release dehydroretronecine/heliotridine which are less reactive toxic metabolites than the dehydroretronecine and dehydroheliotridine toxic metabolites. These metabolites form new adducts leading to chronic diseases such as cancer, pulmonary hypertension, fibrosis of the liver and cirrhosis. 
<smiles>C/C=C1\C(=O)O[C@H]2CCN3CC=C(COC(=O)[C@](O)(CO)C[C@@H]1C)[C@H]23</smiles>

Retrorsine

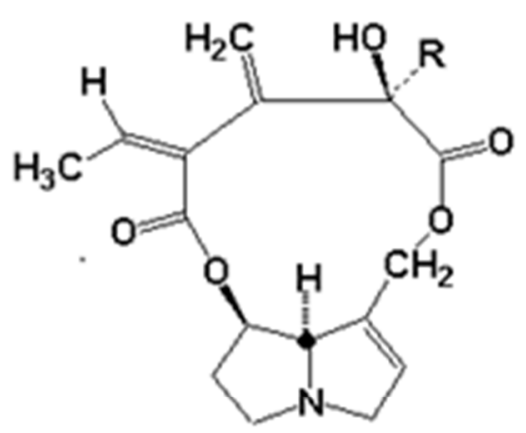

NAME

$\mathbf{R}$

Seneciphylline $\quad \mathrm{H}$ Riddelliine $\quad \mathrm{CH}_{2} \mathrm{OH}$

Figure 2a

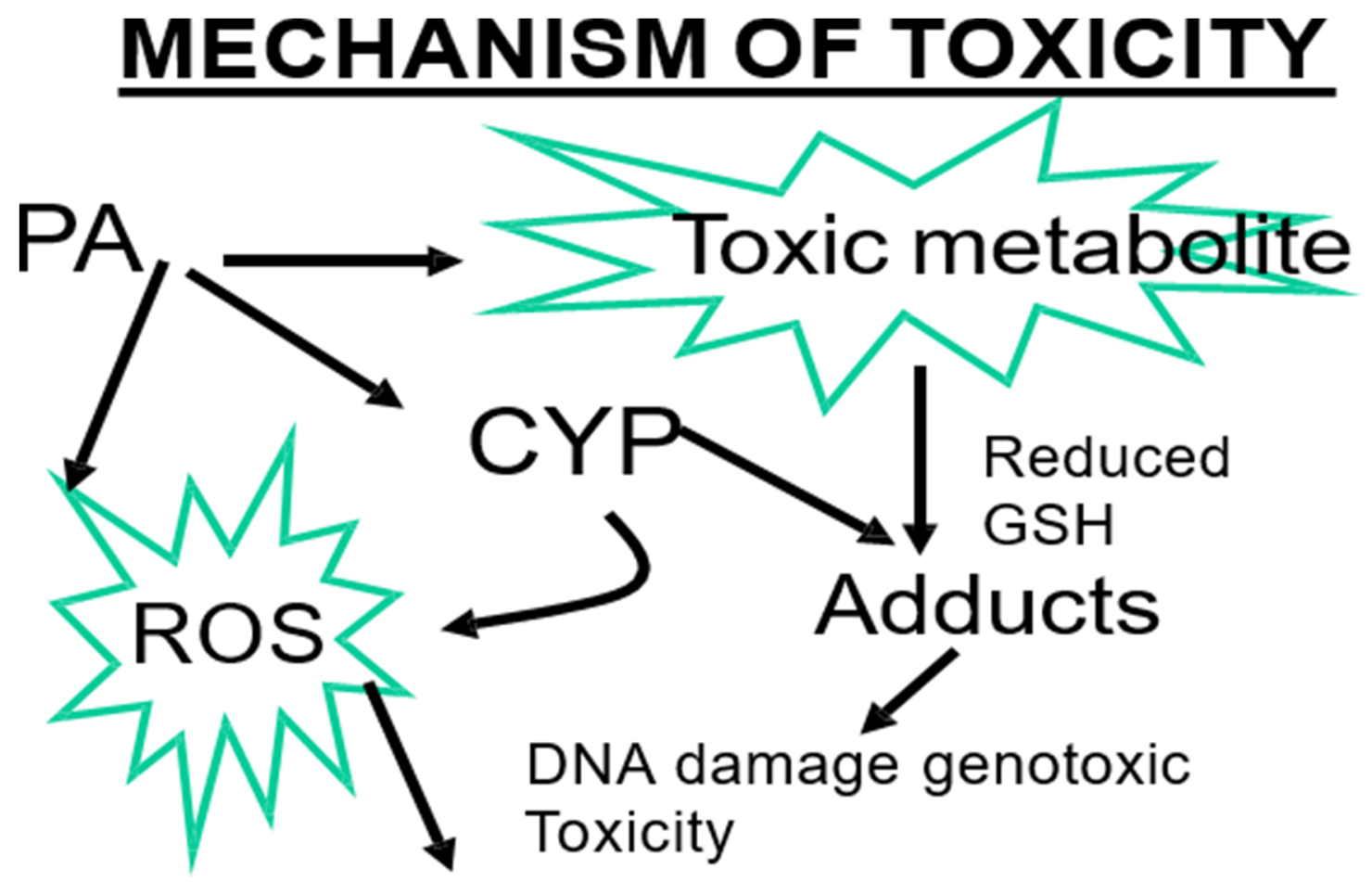

Figure 2b. CYP - Cytochrome P450s, PA-pyrrolizidine alkaloids, RSO - reactive oxygen species, GSH-Gluthatione.

PAs and cancer

Culvenor firstly reported the tumor-inhibiting 
activity of PA isolated from Senecio mikanioides due to the compound's ability to alkylate biological molecules (146). Further investigation found indicine $\mathrm{N}$-oxide as a lead compound for cancer therapy since less severe hepatotoxicity in animal models was shown relative to other PAs (147). Indicine $\mathrm{N}$-oxide is a PA found in Heliotropium indicium and has been produced semi-synthetically for phase I and II clinical trials in patients with advanced solid tumors and leukemia (148-151). Kovach et al. noticed that administering daily doses of $3.0 \mathrm{~g} / \mathrm{m}^{2}$ for five consecutive days to advanced cancer patients showed symptoms of myelosuppression but no significant hepatic and renal impairment (152). Furthermore, three patients with advanced gastrointestinal cancer had no definite therapeutic response to indicine $\mathrm{N}$ - oxide and its ability to treat solid tumors (152).

The clinical trial of indicine $\mathrm{N}$-oxide in acute leukemia patients conducted by Letendre et al. failed to show therapeutic improvement. Five out of eleven patients experienced severe hepatotoxicity and four resulted in death due to liver failure (153). A five year-old boy with acute myelocytic leukemia was given $7.5 \mathrm{~g} / \mathrm{m}^{2}$ indicine $\mathrm{N}$-oxide after two complete remissions with standard chemotherapeutic agents. Three days later, the patient showed signs of acute hepatic failure, and died nine days later with hepatic necrosis (154). A phase I clinical trial was carried out by Whitehead et al. using indicine $\mathrm{N}$-oxide to treat children with leukemia or solid tumors who failed to show progress on standard chemotherapy. Myelosuppression and hepatotoxicity limited the dose of indicine N-oxide in pediatric patients with solid tumors and leukemia, respectively (150). Further, no clinically significant objective responses were noted in patients, thus disappointingly ceasing the scientific investigation into indicine $\mathrm{N}$-oxide. Miser et al. (155) carried out a phase II clinical trial in children with relapsed acute leukemia and although indicine $\mathrm{N}$-oxide showed some anti-leukemic activity, it was associated with severe and irreversible hepatotoxicity. PA appears to be a compound of interest for anti-cancer therapy due to its cytotoxic and angiogenesis inhibiting property. However, as a result of its severe hepatotoxicity, clinical application is limited.

PAs found in several commonly consumed plants are potential carcinogens or tumor promoters and should be avoided (156). Also, the Traditional
Indian medicine, Ayurveda, uses medicinal plants which contain toxic PAs which represent a severe mutagenic and cancerogenic risk (157). The carcinogenic species of PAs (e.g. echimidine and jacobine), namely pyrrole-type metabolites, are generated by hepatic CYP2B6 and CYP3A4 (158). Roeder and his team described PA chemical structure and the use of PA-containing remedies in the world (159-161). In their recent review article, Roeder et al. (162) also mention that PAs are mutagenic, carcinogenic, and teratogenic. In addition, the authors recognized the need to identify and to regulate PA-containing medications. While the mainstay of therapy for herbal hepatotoxicity is withdrawal of the offending toxin, early recognition of toxicity is important to permit assessment of severity and monitoring for liver damage. However of importance is prevention of the toxic event.

\section{Regulation of herbal remedies}

Regulation of the safety, efficacy and quality of herbal remedies is greater in the Europe (EU) than in the United States (US). Complementary and Alternative Medicine in the United States receives recommendation from the Institute of Medicine Committee on the Use of Complementary and Alternative Medicine regarding the possible use of herbal remedies by the American Public (163). In addition, FDA regulates the safety and efficacy of the complementary and alternative medication as well as of the amount of PA in food and natural related products (164-169). EU requires manufacturers of all over-the-counter herbal products to register and license the product with the European Agency for the Evaluation of Medicinal Products. A premarket evaluation of quality and safety of the product is required. Companies have been asked to carry out post- marketing surveillance and report serious adverse events. Instead of requiring new rigorous efficacy studies to market a new product, documentation from the medical literature of safety for the relevant condition and reasonable plausibility of efficacy is needed. The World Health Organization (WHO) developed a Traditional Medicine Strategy to promote the safety of the complementary and alternative medicine as well as to regulate the poisonous substances of natural origin that may be found in food (164). As part of this effort, the WHO distributed a survey about national policies and regulations for herbal medicines to help frame regulatory policies, enhance quality, safety and efficacy. The potential PA contamination of 
food, herbal medicine, herbal teas, dietary supplements or food containing PA plant material representing potential threat to human health by PAs is studied. In pharmaceuticals, the use of these plants is regulated.

Drying pollen granules during processing reduces the dehydroPA content of the granules (173). Nevertheless, 17 (31\%) of 55 commercial bee-pollen products purchased at retail outlets in Europe have been found to contain $1080-16350 \mathrm{mg} / \mathrm{kg}^{1}$ of dehydro-PAs mainly from Echium species (172). Echium sp. pollen has a characteristic deep purple colour and bee-collected pollen granules from Echium $s p$. have been observed, and in some cases confirmed by scanning electron microscopy, while Senecio pollen cannot be distinguish from the other plant's pollen.

Consideration of the PA concentrations observed in honey from PA containing plants and pollen products led to an international regulation of PAs in food. Safe doses for PA in dietary and herbal remedies as well as in honey and pollen in different EU countries (171-174).

Harmonization of the market for herbal medicines is a fundamental requirement for European industries and health professionals. Herbal medicines can be also sold as food supplements, which required a common regulatory status in the various European countries. The European Parliament and by the Council of Europe established that herbal medicines released in the market need authorization by the national regulatory authorities of each European country and that these products must have a recognized level of safety and efficacy. In 1992, the Federal Health Department of Germany has restricted "the manufacture and use of pharmaceuticals containing pyrrolizidine alkaloids with a unsaturated necine skeleton". The herbal plants "may be sold and used only if daily external exposure to no more than $100 \mu \mathrm{g}$ pyrrolizidine alkaloids and internal exposure to no more than $1 \mu \mathrm{g}$ per day for no more than six weeks a year.

In Europe, marketing of traditional herbal medicinal products is regulated by an ad hoc Directive (i.e. Directive 2004/24/EC). Food Standards Australia New Zealand (FSANZ) has proposed a TDI for dehydro-PAs of $1 \mu \mathrm{g} \mathrm{kg}$ body weight/day. This is higher than those determined by other authorities partly due to FSANZ considering the cancer risk to humans to be unproven and also to be unlikely due to a more efficient DNA-repair system in humans (FSANZ 2001). FSANZ recommends dilution of contaminated product with uncontaminated product to achieve the recommended level (FSANZ 2004), a practice not allowed in some other jurisdictions (European Food Safety Authority (EFSA) 2007). In addition, Senecio spp. is prohibited for therapeutic use in Australia.

The safety of herbal medicinal products needed to be evaluated on the basis of existing scientific literature (data from clinical studies, case reports, pre-clinical studies). Based upon the safety and efficacy data, herbal medicinal products are categorized as: (i) medicinal herbs with a recognized level of safety and efficacy; and (ii) traditional used medicinal herbs that do not have a recognized level of efficacy but are acceptably safe (175-183).

DehydroPAs relative to consumption of honey containing dehydroPAs tolerable daily intakes was determined by German (Bundesanzeiger 1992) and Dutch (Rijksinstituut voor Volksgezondheid en Milieu (RIVM) 2007) to be $0.1 \mathrm{microgram} /$ day. Australian and New Zealand (Food Standards Australia-New Zealand (FSANZ) 2001) authorities (175-183).

Not all the countries regulate the type as quantity of PA containing foods and remedies. Qianliguang is traditional herbal medicine growing in different locations of China. Significant diversity of the PA types and quantities were revealed among the samples tested (184-185). The estimated total amounts of toxic PAs in some of the samples exceed the toxic limits of PA intake restricted by WHO, demonstrating the timely and high demand for regulating both types and quantities of PAs present in Qianliguang as well as food containing PAs (184185). Moreover, Qianliguang is used also as herbal remedy in Europe. The United Kingdom Medicines and Healthcare Product Regulatory Agency restricted PAs in this herbal product to $1 \mathrm{mg} /$ day (or $16.7 \mu \mathrm{g} / \mathrm{kg} / \mathrm{day}$ for a $60-\mathrm{kg}$ body weight) for 2 weeks and to $0.1 \mu \mathrm{g} / \mathrm{day}(1.67 \mu \mathrm{g} / \mathrm{kg} /$ day $)$ for a longer period (186). Pharmacopoeia of P.R. China (2010 edition) stated that adonifoline in Qianliguang should not exceed $0.004 \%$ ( $40 \mu \mathrm{g} / \mathrm{g}$ of dried herb) (187). However, in addition to adonifoline there are other PAs (retronecine and the toxic otonecine-type PAs)in the same herb (185).

\section{CONCLUSION}

$P A$-induced toxicity demonstrates the lack of pharmacovigilance regarding traditional medicine and herbal supplements. Therefore, a greater degree 
of safety regulation is required to assess the toxicological profiles of traditional medicine and herbal supplements that are available to the public. Moreover, stronger agricultural protocols to mitigate Senecio poisoning in livestock, as well as regulatory policies regarding safety of traditional medicine, is of utmost importance. In addition, individuals with pre-existing liver injury or simultaneously taking drugs of use or misuse that induce certain cytochrome $\mathrm{p} 450$ s may be more susceptible to PAinduced hepatotoxicity. Also should be taken into account the likelihood and significance of intermittent level dietary exposure to PA as well as the potentiating effects of environmental copper and genetic factors. Another important factor is that the methods of determining the quality and quantity of PAs in remedies and foods should be standardized.

The work presented in this paper may contribute to finding a rational approach to limit or prevent liver damage due to herbal remedies. Based on our clinical cases of herbal remedy-induced liver damage, this subject deserves further investigation. From a social point of view, the present investigation on the mechanism of herbal remedy-induced HSOS may assist in gaining a larger recognition of the problem, which will be required for the development of educational strategies aimed at informing physicians and the public about the potential dangers of these commonly used remedies. A recommended strategy is to inform the consumers in articles which are written in plain language, as well as, answering the key questions an individual might have about a given herbal product or condition. Another possible strategy is to encourage physicians to ask their patients about the use of complementary and alternative medicine.

The market of herbal remedies and dietary supplements has to ensure: (a) security in composition, (b) definition of influence of metabolic aspects, including scientific validation and (c) regulatory aspects, e.g. the claims definition and relative influences.

\section{ACKNOWLEDGEMENTS}

In Vitro Drug Safety and Biotechnology and Mahaffy Gastroenterology grant, Sunnybrook Hospital, for the financial support.

\section{REFERENCES}

1. Tindle HA, Davis RB, Phillips RS, Eisenberg DM.
Trends in use of complementary and alternative medicine by US adults: 1997-2002. Altern Ther Health Med, 2005;11:42-9.

2. MacLennan AH, Wilson DH, Taylor AW. Prevalence and cost of alternative medicine in Australia. Lancet, 1996;347:569-73.

3. Barnes PM, Bloom B, Nahin RL. Complementary and alternative medicine use among adults and children: United States, 2007. Natl Health Stat Report, 2008;12:1-23.

4. Bailey RL, Gahche JJ, Lentino CV, Dwyer JT, Engel JS, Thomas PR, Betz JM, Sempos CT, Picciano MF. Dietary supplement use in the United States, 20032006. J Nutr, 2011;141:261-6.

5. Bailey RL, Gahche JJ, Miller PE, Thomas PR, Dwyer JT. Why US adults use dietary supplements. JAMA Intern Med, 2013;173:355-61.

6. Nahin RL, Barnes PM, Stussman BJ, Bloom B. Costs of complementary and alternative medicine (CAM) and frequency of visits to CAM practitioners: United States, 2007. Natl Health Stat Report, 2009;18:1-14.

7. Bodenstein JW. Toxicity of traditional herbal remedies. S Afr Med J, 1977;52:790.

8. Bateman J, Chapman RD, Simpson D. Possible toxicity of herbal remedies. Scott Med J, 1998;43:715.

9. Saydah SH, Eberhardt MS. Use of complementary and alternative medicine among adults with chronic diseases: United States 2002. J Altern Complement Med, 2006;12:805-12.

10. Zimmerman HJ. Hepatic Metabolism of Foreign Compounds. In Hepatotoxicity. The adverse effects of drugs and other chemicals on the Liver pp. 11-40. 1999. Lippincott Williams \& Wilkins: Philadelphia.

11. Goldman P. Herbal medicines today and the roots of modern pharmacology. Ann Intern Med, 2001;135:594-600.

12. Kennedy J. Herb and supplement use in the US adult population. Clin Ther, 2005;27:1847- 58.

13. Navarro VJ. Herbal and dietary supplement hepatotoxicity. Semin Liver Dis, 2009;29:373- 82.

14. Zimmerman HJ. Vulnerability of the Liver to Toxic Injury. In Hepatotoxicity. The adverse effects of drugs and other chemicals on the Liver pp. 41-60. 1999. Lippincott Williams \& Wilkins: Philadelphia.

15. Popat A, Shear NH, Malkiewicz I, Stewart MJ, Steenkamp V, Thomson S, Neuman MG. The toxicity of Callilepis laureola, a South African traditional herbal medicine. Clin Biochem, 2001;34:229-36.

16. Popat A, Shear NH, Malkiewicz I, Thomson S, Neuman MG. Mechanism of Impila (Callilepis laureola)-induced cytotoxicity in Hep G2 cells. Clin Biochem 35:57-64, 2002.

17. Wainwright J, Schonland MM, Candy HA. Toxicity of Callilepis laureola. S Afr Med J, 1977;52:313-5.

18. Watson AR, Coovadia HM, Bhoola KD. The clinical syndrome of Impila (Callilepis laureola) poisoning in 
children. S Afr Med J, 1979;55:290-2.

19. Joubert PH. Poisoning admissions of black South Africans. J Toxicol Clin Toxicol, 1990;28:85-94.

20. Stewart MJ, Steenkamp V, Zuckerman M. The toxicology of African herbal remedies. Ther Drug Monit, 1998;20:510-6.

21. Venter CP, Joubert PH. Aspects of poisoning with traditional medicines in southern Africa. Biomed Environ Sci, 1988;1:388-91.

22. Steenkamp V, Stewart MJ, Zuckerman M. Detection of poisoning by Impila (Callilepis laureola) in a mother and child. Hum Exp Toxicol, 1999;18:594-7.

23. Stewart MJ, Moar JJ, Steenkamp P, Kokot M. Findings in fatal cases of poisoning attributed to traditional remedies in South Africa. Forensic Sci Int, 1999; 101:177-83.

24. van Wyk BE, Verdoorn GH, Schutte AL. Distribution and taxonomic significance of major alkaloids in the genus Podalyria. Biochem Syst Ecol, 1992;20:163172.

25. Wainwright J, Schonland MM. Toxic hepatitis in black patients in Natal. S Afr Med J, 1977;51:571-3.

26. Pessayre D, Feldman G, Haouzi D, Fau A, Moreau A, Neuman MG: Hepatocyte apoptosis triggered by natural substances (cytokines, other endogenous molecules and foreign toxins). In Chapter 3, In: Cameron RG, Fauer G, eds. Handbook of Experimental Pharmacology: Apoptosis modulation by drugs. Vol. 142, Chapter 3. Heidelberg: Springer Verlag Publishers, 1999:69-109.

27. Grue MR, Liddell JR. Pyrrolizidine alkaloids from Senecio chrysocoma. Phytochem, 1993;33:15171519.

28. Smith LW, Culvenor CC. Plant sources of hepatotoxic pyrrolizidine alkaloids. J Nat Prod, 1981; 44:129-52.

29. Mattocks AR. Toxicity of pyrrolizidine alkaloids. Nature, 1968;217:723-8.

30. Seeff LB. Herbal hepatotoxicity. Clin Liver Dis, 2007;11:577-96.

31. Bach N, Thung SN, Schaffner F. Comfrey herb teainduced hepatic veno-occlusive disease. Am J Med, 1989;87:97-9.

32. Ridker PM, McDermott WV. Comfrey herb tea and hepatic veno-occlusive disease. Lancet, 1989;1:6578.

33. Weston CF, Cooper BT, Davies JD, Levine DF. Veno-occlusive disease of the liver secondary to ingestion of comfrey. Br Med J (Clin Res Ed), 1987;295:183.

34. Yeong ML, Swinburn B, Kennedy M, Nicholson G. Hepatic veno-occlusive disease associated with comfrey ingestion. J Gastroenterol Hepatol, 1990;5:211-4.

35. Stickel F, Seitz HK. The efficacy and safety of comfrey. Public Health Nutr, 2000;3:501-8.

36. Moro PA, Cassetti F, Giugliano G, Falce MT,
Mazzanti G, Menniti-Ippolito F, Raschetti R, Santuccio C. Hepatitis from Greater celandine (Chelidonium majus L.): review of literature and report of a new case. J Ethnopharmacol, 2009;124:328-32.

37. Stickel F, Pöschl G, Seitz HK, Waldherr R, Hahn EG, Schuppan D. Acute hepatitis induced by Greater Celandine (Chelidonium majus). Scand J Gastroenterol, 2003;38:565-568.

38. Benninger J, Schneider HT, Schuppan D, Kirchner T, Hahn EG. Acute hepatitis induced by greater celandine (Chelidonium majus). Gastroenterology, 1999;117:1234-7.

39. Crijns AP, de Smet PA, van den Heuvel M, Schot BW, Haagsma EB. Acute hepatitis after use of a herbal preparation with greater celandine (Chelidonium majus). Ned Tijdschr Geneeskd, 2002;146:124-8.

40. Wang JY, Gao H: Tusanqi and hepatic sinusoidal obstruction syndrome. J Dig Dis. 2014 Mar;15(3):105-7. doi: 10.1111/1751-2980.12112.

41. Greving I, Meister V, Monnerjahn C, Müller KM, May B. Chelidonium majus: a rare reason for severe hepatotoxic reaction. Pharmacoepidemiol Drug Saf, 1998;7 Suppl 1:S66- 9.

42. Rifai K, Flemming P, Manns MP, Trautwein C. Severe drug hepatitis caused by Chelidonium. Internist (Berl), 2006;47:749-51.

43. Teschke R, Glass X, Schulze J, Eickhoff A. Suspected Greater Celandine hepatotoxicity: liverspecific causality evaluation of published case reports from Europe. Eur J Gastroenterol Hepatol, 2012;24:270-80.

44. Teschke R, Glass X, Schulze J. Herbal hepatotoxicity by Greater Celandine (Chelidonium majus): causality assessment of 22 spontaneous reports. Regul Toxicol Pharmacol, 2011;61:282-91.

45. Teschke R. Kava hepatotoxicity: pathogenetic aspects and prospective considerations. Liver Int, 2010;30:1270-9.

46. Lechtenberg M(1), Quandt B, Schmidt M, Nahrstedt A. Is the alkaloid pipermethystine connected with the claimed liver toxicity of Kava products? Pharmazie. 2008;63(1):71-4.

47. Bonkovsky HL. Hepatotoxicity associated with supplements containing Chinese green tea (Camellia sinensis). Ann Intern Med, 2006;144:68-71.

48. Molinari M, Watt KD, Kruszyna T, Nelson R, Walsh M, Huang WY, Nashan B, Peltekian Acute liver failure induced by green tea extracts: case report and review of the literature. Liver Transpl, 2006;12:18925.

49. Tandon HD, Tandon BN, Ramalingaswami V. Epidemic of toxic hepatitis in India of possible mycotoxic origin. Arch Pathol Lab Med, 1978; 102:372-6.

50. Bras G, Brooks SEH, Watler DC. Cirrhosis of liver in 
Jamaica. J Pathol Bacteriol. 1961, 82:503-512.

51. Neuman MG, Steenkamp V. Toxicity profile of pyrrolizidine alkaloid-containing medicinal plants: Emphasis on Senecio species. Intl J Biomed Pharma Sci, 2009;3:104-8.

52. Neuman MG, Schneider M, Nanau RM, Parry C, Chersich M. The relationship between alcohol consumption and human immunodeficiency virus infection and risk behaviour: A systematic literature review of high-risk groups, with a focus on South Africa; Chapter 13, In: Public Health - Social and Behavioral Health, InTech Open Publication, pp. 243-92, 2012. Rijeka, Croatia.

53. McLean E. The toxic actions of pyrrolizidine (Senecio) alkaloids. Pharmacol Rev, 1970;22:429-83.

54. Zimmerman HJ, Ishak KG. General aspects of druginduced liver disease. Gastroenterol Clin North Am, 1995;24:739-57.

55. Valla D, Benhamou JP. Drug-induced vascular and sinusoidal lesions of the liver. Baillieres Clin Gastroenterol, 1988;2:481-500.

56. Bryant AT. Zulu medicine and medicine-men. Annals of Natal Museum, 1909;2:1-103.

57. Bye SN, Dutton MF. The inappropriate use of traditional medicines in South Africa. J Ethnopharmacol, 1991;34:253-9.

58. Teschke R, Genthner A, Wolff A. Kava hepatotoxicity: comparison of aqueous, ethanolic, acetonic kava extracts and kava-herbs mixtures. J Ethnopharmacol, 2009;123:378-84.

59. Bondan C, Soares JC, Cecim M, Lopes ST, Graça DL, da Rocha RX. Oxidative stress in the erythrocytes of cattle intoxicated with Senecio sp. Vet Clin Pathol, 2005;34:353-7.

60. Steenkamp V, Stewart MJ, Zuckerman M. Clinical and analytical aspects of pyrrolizidine poisoning caused by South African traditional medicines. Ther Drug Monit, 2000;22:302- 306.

61. McGaw LJ, Eloff JN. Ethnoveterinary use of southern African plants and scientific evaluation of their medicinal properties. J Ethnopharmacol, 2008;119:559-574.

62. Birecka H, Catalfamo J, Eisen R. A sensitive method for the detection and quantitative determination of pyrrolizidine alkaloids. Phytochemistry, 1981;20:343-4.

63. Mattocks A. Spectrophotometric determination of pyrrolizidine alkaloids- some improvements. Anal Chem, 1968;40:1749-50.

64. Culvenor CCJ, Edgar JA, Smith LW, Tweedale HJ. Dihydropyrrolizines III. Preparation and reactions of derivatives related to pyrrolizidine alkaloids. Aust J Chem. 1970, 23:1853-1867.

65. Steenkamp V, von Arb M, Stewart M. Metal concentrations in plants and urine from patients treated with South African traditional remedies. Forensic Sci Int, 2000;114:89-95.
66. Laurens T, Bekker L, Steenkamp V, Stewart M. Gas chromatographic-mass spectrophotometric confirmation of atractyloside in a patient poisoned with Callilepis laureola. J Chromatogr (B), 2001;765:127-33.

67. Crews C, Berthiller F, Krska R. Update on analytical methods for toxic pyrrolizidine alkaloids. Anal Bioanal Chem, 2010;396:327-38.

68. Anderson IB, Mullen WH, Meeker JE, KhojastehBakhtSC, Oishi S, Nelson SD, Blanc PD. Pennyroyal toxicity: measurement of toxic metabolite levels in two cases and review of the literature. Ann Intern Med, 1996;124:726-34.

69. Rosemann GM, Botha CJ, Eloff JN. Distinguishing between toxic and non-toxic pyrrolizine alkaloids and quantification by liquid chromatography-mass spectrometry. Phytochem Lett, 2014;8:126-131.

70. Oplatowska M, Elliott CT, Huet AC, McCarthy M, Mulder PP, von Holst C, Delahaut P, Van Egmond HP, Campbell K. Development and validation of a rapid multiplex ELISA for pyrrolizidine alkaloids and their N-oxides in honey and feed. Anal Bioanal Chem, 2014;406:757-70.

71. Griffin CT, Danaher M, Elliott CT, Glenn Kennedy D, Furey A. Detection of pyrrolizidine alkaloids in commercial honey using liquid chromatography-ion trap mass spectrometry. Food Chem, 2013;136:157783.

72. Martinello M, Cristofoli C, Gallina A, Mutinelli F. Easy and rapid method for the quantitative determination of pyrrolizidine alkaloids in honey by ultra performance liquid chromatography-mass spectrometry: an evaluation in commercial honey. Food Control, 2014;37:146-152.

73. Ridker PM, Ohkuma S, McDermott WV, Trey C, Huxtable RJ. Hepatic venocclusive disease associated with the consumption of pyrrolizidine-containing dietary supplements. Gastroenterology, 1985;88:1050-4.

74. Schiano TD. Liver injury from herbs and other botanicals. Clin Liver Dis, 1998; 2:607-36.

75. International Programme on Chemical Safety. Pyrrolizidine alkaloids. Environmental health criteria. World Health Organization, Geneva, 1988.

76. Lindigkeit R, Biller A, Buch M, Schiebel HM, Boppré M, Hartmann T. The two facies of pyrrolizidine alkaloids: the role of the tertiary amine and its N-oxide in chemical defense of insects with acquired plant alkaloids. Eur J Biochem, 1997;245:626-36.

77. Hartmann T. Chemical ecology of pyrrolizidine alkaloids. Planta, 1999;207:483-95.

78. Habermehl GG, Martz W, Tokarnia CH, Döbereiner J, Mendez MC. Livestock poisoning in South America by species of the Senecio plant. Toxicon, 1988;26:275-86.

79. Schoental R. Hepatotoxic action of pyrrolizidine 
(Senecio) alkaloids in relation to their structure. Nature, 1957;179:361-3.

80. Cooper RG. Unusual case of Senecio sceleratus (Ragword) poisoning in an ostrich (Struthio camelus) in Zimbabwe. Turk J Vet Anim Sci, 2007;31:143-4.

81. Kellerman TS, Naudé TW, Fourie N. The distribution, diagnoses and estimated economic impact of plant poisonings and mycotoxicoses in South Africa. Onderstepoort J Vet Res, 1996;63:6590.

82. Giles CJ. Outbreak of ragword (Senecio jacobea) poisoning in horses. Equine Vet J, 1983;15:248-50.

83. Vandenbroucke V, Van Pelt H, De Backer P, Croubels S. Animal poisonings in Belgium: a review of the past decade. Vlaams Diergeneeskundig Tijdschrift, 2010;79:259-68.

84. Passemard B, Priymenko N. Equine poisoning by Senecio in France. Revue Med Vet, 2007;158:425-30.

85. McLaren DA, Ireson JE, Kwong RM. Biological control of ragwort (Senecio jacobaea L.) in Australia. Proceedings of the X International Symposium on Biological Control of Weeds, 2000;67-79. Available at http://www.invasive.org/proceedings/pdfs/10_6779.pdf.

86. Moyano MR, García A, Rueda A, Molina AM, Mendez A, Infante F. Echium vulgare and Senecio vulgaris poisoning in fighting bulls. J Vet Med A Physiol Pathol Clin Med, 2006;53:24-5.

87. de Barros CS, Driemeier D, Pilati C, Barros SS, Castilhos LM. Senecio spp poisoning in cattle in southern Brazil. Vet Hum Toxicol, 1992;34:241-6.

88. Gava A, Barros CS. Senecio spp. poisoning of horses in southern Brazil. Preq Vet Bras, 1997;17:36-40.

89. Giaretta PR, Panziera W, Hammerschmitt ME, Bianchi RM, Galiza G, Wiethan IS, Bazzi T, Barros C. Clinical and pathological aspects of chronic Senecio spp. poisoning in sheep. Pesq Vet Bras, 2014;34:967-973.

90. Giaretta PR, Panziera W, Galiza GJ, Brum JS, Bianchi RM, Hammerschmitt ME, Bazzi T, Barros CS. Senecio in cattle associated with pthosensitization. Pesq Vet Bras, 2014;34:427- 432.

91. Tokarnia CH, Döbereiner J, Peixoto PV. Poisonous plants affecting livestock in Brazil. Toxicon, 2002;40:1635-60.

92. de Lanux-Van Gorder V. Tansy ragwort poisoning in a horse in southern Ontario. Can Vet J, 2000;41:40910 .

93. Stegelmeier BL. Pyrrolizidine alkaloid-containing toxic plants (Senecio, Crotalaria, Cynoglossum, Amsinckia, Heliotropium, and Echium spp.). Vet Clin North Am Food Anim Pract, 2011;27:419-28.

94. Varga A, Puschner B. Retrospective study of cattle poisonings in California: recognition, diagnosis, and treatment. Veterinary Medicine: Research and Reports, 2012;3:111-27.

95. Stuart BP, Cole RJ, Gosser HS. Cocklebur (Xanthium strumarium, L. var. strumarium) intoxication in swine: review and redefinition of the toxic principle. Vet Pathol, 1981;18:368-83.

96. Witte ST, Osweiler GD, Stahr HM, Mobley G. Cocklebur toxicosis in cattle associated with the consumption of mature Xanthium strumarium. J Vet Diagn Invest, 1990;2:263-7.

97. Crews C, Driffield M, Berthiller F, Krska R. Loss of pyrrolizidine alkaloids on decomposition of ragwort (Senecio jacobaea) as measured by LC-TOF-MS. J Agric Food Chem, 2009;57:3669-73.

98. Roberts PD, Pullin AS. The effectiveness of management interventions used to control ragwort species. Environ Manage, 2007;39:691-706.

99. Bolechová M, Cáslavský J, Pospíchalová M, Kosubová P. UPLC-MS/MS method for determination of selected pyrrolizidine alkaloids in feed. Food Chem, 2015;170:265-70.

100.Jacobs J, Sing S. Ecology and management of tansy ragword (Senecio jacobaea L.). United States Department of Agriculture Natural Resources Conservation Service Invasive Species Technical Note, 2009;1-13. Available at http://www.fs.fed.us/rm/pubs_other/rmrs_2009_jaco bs_j001.pdf.

101.McGee J, Patrick RS, Wood CB, Blumgart LH. A case of veno-occlusive disease of the liver in Britain associated with herbal tea consumption. J Clin Pathol, 1976;29:788-94.

102. Kumana CR, Ng M, Lin HJ, Ko W, Wu PC, Todd D. Herbal tea induced hepatic veno-occlusive disease: quantification of toxic alkaloid exposure in adults. Gut, 1985;26:101-4.

103. Sperl W, Stuppner H, Gassner I, Judmaier W, Dietze O, Vogel W. Reversible hepatic veno-occlusive disease in an infant after consumption of pyrrolizidine-containing herbal tea. Eur J Pediatr, 1995;154:112-6.

104.Schulz M, Meins J, Diemert S, Zagermann-Muncke P, Goebel R, Schrenk D, Schubert-Zsilavecz M, Abdel-Tawab M. Detection of pyrrolizidine alkaloids in German licensed herbal medicinal teas. Phytomedicine, 2015;22:648-56.

105.U.S. Food and Drug Administration. FDA advises dietary supplement manufacturers to remove comfrey products from the market, 2001. Accessed Aug 10 2015. Available at http://www.fd.gov/Food/DietarySupplements/Alerts/ ucm111219.htm.

106. Mädge I, Cramer L, Rahaus I, Jerz G, Winterhalter P, Beuerle T. Pyrrolizidine alkaloids in herbal teas for infants, pregnant or lactating women. Food Chem, 2015;187:491-8.

107.Deinzer ML, Thomson PA, Burgett DM, Isaacson DL. Pyrrolizidine alkaloids: their occurrence in honey from tansy ragword (Senecio jacobaea L.). Science, 1977;195:494-9. 
108.Edgar JA, Roeder E, Molyneux RJ. Honey from plants containing pyrrolizidine alkaloids: a potential threat to health. J Agric Food Chem, 2002;50:271930 .

109.Dübecke A, Beckh G, Lüllmann C. Pyrrolizidine alkaloids in honey and bee pollen. Food Addit Contam Part A Chem Anal Control Expo Risk Assess, 2011;28:348-58.

110.Edgar JA, Colegate SM, Boppré M, Molyneux RJ. Pyrrolizidine alkaloids in food: a spectrum of potential health consequences. Food Addit Contam Part A Chem Anal Control Expo Risk Assess, 2011;28:308-24.

111.Kempf M, Wittig M, Reinhard A, von der Ohe K, Blacquière T, Raezke KP, Michel R, Schreier P, Beuerle T. Pyrrolizidine alkaloids in honey: comparison of analytical methods. Food Addit Contam Part A Chem Anal Control Expo Risk Assess, 2011;28:332- 47.

112.Kempf M, Wittig M, Schönfeld K, Cramer L, Schreier P, Beuerle T. Pyrrolizidine alkaloids in food: downstream contamination in the food chain caused by honey and pollen. Food Addit Contam Part A Chem Anal Control Expo Risk Assess, 2011;28:32531.

113. Griffin CT, O’Mahony J, Danaher M, Furey A. Liquid chromatography tandem mass spectrometry detection of targeted pyrrolizidine alkaloids in honeys purchased within Ireland. Food Anal Methods, 2015;8:18-31.

114.Hoogenboom LA, Mulder PP, Zeilmaker MJ, van den Top HJ, Remmelink GJ, Brandon EF, Klijnstra M, Meijer GA, Schothorst R, Van Egmond HP. Carryover of pyrrolizidine alkaloids from feed to milk in dairy cows. Food Addit Contam Part A Chem Anal Control Expo Risk Assess, 2011;28:359-72.

115.Kakar F, Akbarian Z, Leslie T, Mustafa ML, Watson J, van Egmond HP, Omar MF, Mofleh J. An outbreak of hepatic veno-occlusive disease in Western afghanistan associated with exposure to wheat flour contaminated with pyrrolizidine alkaloids. J Toxicol, 2010;2010:313280.

116. Auerbach BJ, Reynolds SJ, Lamorde M, Merry C, Kukunda-Byobona C, Ocama P, Semeere AS, Ndyanabo A, Boaz I, Kiggundu V, Nalugoda F, Gray RH, Wawer MJ, Thomas DL, Kirk GD, Quinn TC, Stabinski L. Traditional herbal medicine use associated with liver fibrosis in rural Rakai, Uganda. PLoS One, 2012;7:e41737.

117.Kassler WJ, Blanc P, Greenblatt R. The use of medicinal herbs by human immunodeficiency virusinfected patients. Arch Intern Med, 1991;151:2281-8.

118.Ishak KG. Hepatic lesions caused by anabolic and contraceptive steroids. Semin Liver Dis, 1981;1:11628.

119. Willmot FC, Robertson GW. Senecio disease, or cirrhosis of the liver due to Senecio poisoning.
Lancet, 1920;196:848-849.

120.Richardson P, Guinan E. The pathology, diagnosis, and treatment of hepatic veno- occlusive disease: current status and novel approaches. Br J Haematol, 1999;107:485-93.

121. Wadleigh M, Ho V, Momtaz P, Richardson P. Hepatic veno-occlusive disease: pathogenesis, diagnosis and treatment. Curr Opin Hematol, 2003; 10:451-62.

122.DeLeve LD, Shulman HM, McDonald GB. Toxic injury to hepatic sinusoids: sinusoidal obstruction syndrome (veno-occlusive disease). Semin Liver Dis, 2002;22:27- 42 .

123.Chojkier M. Hepatic sinusoidal-obstruction syndrome: toxicity of pyrrolizidine alkaloids. J Hepatol, 2003;39:437-46.

124.Ji LL, Zhang M, Sheng YC, Wang ZT. Pyrrolizidine alkaloid clivorine induces apoptosis in human normal liver L-02 cells and reduces the expression of p53 protein. Toxicol In Vitro, 2005;19:41-6.

125.Zuckerman M, Steenkamp V, Stewart MJ. Hepatic veno-occlusive disease as a result of a traditional remedy: confirmation of toxic pyrrolizidine alkaloids as the cause, using an in vitro technique. J Clin Pathol, 2002;55:676-9.

126.Coppell JA, Brown SA, Perry DJ. Veno-occlusive disease: cytokines, genetics, and haemostasis. Blood Rev, 2003;17:63-70.

127. Robaye B, Mosselmans R, Fiers W, Dumont JE, Galand P. Tumor necrosis factor induces apoptosis (programmed cell death) in normal endothelial cells in vitro. Am J Pathol, 1991;138:447-53.

128.DeLeve LD, Shulman HM, McDonald GB. Toxic injury to hepatic sinusoids: sinusoidal obstruction syndrome (veno-occlusive disease). Semin Liver Dis, 2002;22:27- 42 .

129. Katz GG, Shear NH, Malkiewicz IM, Valentino K, Neuman MG. Signaling for ethanol-induced apoptosis and repair in vitro. Clin Biochem, 2001;34:219-27.

130.Xiong A, Yang F, Fang L, Yang L, He Y, Wan YJ, Xu Y, Qi M, Wang X, Yu K, Tsim KW, Wang Z. Metabolomic and genomic evidence for compromised bile acid homeostasis by senecionine, a hepatotoxic pyrrolizidine alkaloid. Chem Res Toxicol, 2014;27:775-86.

131.Xiong A, Fang L, Yang X, Yang F, Qi M, Kang H, Yang L, Tsim KW, Wang Z. An application of target profiling analyses in the hepatotoxicity assessment of herbal medicines: comparative characteristic fingerprint and bile acid profiling of Senecio vulgaris and Senecio scandens Buch.-Ham. Anal Bioanal Chem, 2014;406:7715-27.

132. Chou MW, Fu PP. Formation of DHP-derived DNA adducts in vivo from dietary supplements and chinese herbal plant extracts containing carcinogenic 
pyrrolizidine alkaloids. Toxicol Ind Health, 2006;22:321-7.

133.Dai J, Zhang F, Zheng J. Retrorsine, but not monocrotaline, is a mechanism-based inactivator of P450 3A4. Chem Biol Interact, 2010;183:49-56.

134.Li N, Xia Q, Ruan J, Fu PP, Lin G. Hepatotoxicity and tumorigenicity induced by metabolic activation of pyrrolizidine alkaloids in herbs. Curr Drug Metab, 2011;12:823-34.

135.Tu M, Li L, Lei H, Ma Z, Chen Z, Sun S, Xu S, Zhou $\mathrm{H}$, Zeng S, Jiang H. Involvement of organic cation transporter 1 and CYP3A4 in retrorsine-induced toxicity. Toxicology, 2014;322:34-42.

136.Fu PP, Xia Q, Lin G, Chou MW. Pyrrolizidine alkaloids-genotoxicity, metabolism enzymes, metabolic activation, and mechanisms. Drug Metab Rev, 2004;36:1-55.

137. Wang YP, Yan J, Fu PP, Chou MW. Human liver microsomal reduction of pyrrolizidine alkaloid $\mathrm{N}$ oxides to form the corresponding carcinogenic parent alkaloid. Toxicol Lett, 2005;155:411-20.

138. Yang Y, Yan J, Churchwell M, Beger R, Chan P, Doerge DR, Fu PP, Chou MW. Development of a (32)P-postlabeling/HPLC method for detection of dehydroretronecine- derived DNA adducts in vivo and in vitro. Chem Res Toxicol, 2001;14:91-100.

139. He YQ, Yang L, Liu HX, Zhang JW, Liu Y, Fong A, Xiong AZ, Lu YL, Yang L, Wang CH, Wang ZT. Glucuronidation, a new metabolic pathway for pyrrolizidine alkaloids. Chem Res Toxicol, 2010;23:591-9.

140.Li YH, Kan WL, Li N, Lin G. Assessment of pyrrolizidine alkaloid-induced toxicity in an in vitro screening model. J Ethnopharmacol, 2013;150:560-7.

141.Nuringtyas TR, Verpoorte R, Klinkhamer PG, van Oers MM, Leiss KA. Toxicity of pyrrolizidine alkaloids to Spodoptera exigua using insect cell lines and injection bioassays. J Chem Ecol, 2014;40:60916.

142. Chen Y, Ji L, Xiong A, Yang L, Wang Z. Involvement of intracellular glutathione in regulating isolineinduced cytotoxicity in human normal liver L-02 cells. Toxicol Ind Health, 2013;29:567-75.

143.Ji L, Liu T, Chen Y, Wang Z. Protective mechanisms of $\mathrm{N}$-acetyl-cysteine against pyrrolizidine alkaloid clivorine-induced hepatotoxicity. J Cell Biochem, 2009;108:424-32.

144.Ji L, Chen Y, Liu T, Wang Z. Involvement of Bcl-xL degradation and mitochondrial-mediated apoptotic pathway in pyrrolizidine alkaloids-induced apoptosis in hepatocytes. Toxicol Appl Pharmacol, 2008;231:393-400.

145. Neuman MG, Jia AY, Steenkamp V. Senecio latifolius induces in vitro hepatocytotoxicity in a human cell line. Can J Physiol Pharmacol, 2007;85:1063-75.

146.Culvenor CC. Tumor-inhibitory activity of pyrrolizidine alkaloid. J. Pharmaceutical Sciences, 1968;57:1112-7.

147.Kugelman M, Liu WC, Axelrod M, McBride TJ, Rao $\mathrm{KV}$. Indicine-N-oxide: the antitumor principle of Heliotropium indicum. Lloydia, 1976;39:125-8.

148.Zalkow LH, Glinski JA, Gelbaum LT, Moore D, Melder D, Powis G. Semisynthetic pyrrolizidine alkaloid N-oxide antitumor agents. Esters of heliotridine. J Med Chem, 1988;31:1520-6.

149. Niwa H, Ogawa T, Yamada K. An efficient enantioselective synthesis of $(+)$ - indicine N-oxide, an antitumor pyrrolizidine alkaloid. Tetrahedron Letters, 1989;30:4985- 6.

150. Whitehead VM, Bernstein ML, Vega R, Vats T, Dyment P, Vietti TJ, Krischer J. Phase I trial of indicine-N-oxide in children with leukemia and solid tumors: a Pediatric Oncology Group study. Cancer Chemother Pharmacol, 1990;26:377-9.

151. Miser JS, Smithson WA, Krivit W, Hughes C, Davis D, Krailo M, Hammond D. Phase II trial of indicine $\mathrm{N}$-oxide in relapsed pediatric solid tumors. A report from the Childrens Cancer Study Group. Invest New Drugs, 1991;9:339-42.

152.Kovach JS, Ames MM, Powis G, Moertel CG, Hahn RG, Creagan ET. Toxicity and pharmacokinetics of a pyrrolizidine alkaloid, indicine $\mathrm{N}$-oxide, in humans. Cancer Res, 1979;39:4540-4.

153.Letendre L, Ludwig J, Perrault J, Smithson WA, Kovach JS. Hepatocellular toxicity during the treatment of refractory acute leukemia with indicine N-oxide. Cancer, 1984;54:1256-9.

154.Cook BA, Sinnhuber JR, Thomas PJ, Olson TA, Silverman TA, Jones R, Whitehead VM, Ruymann FB. Hepatic failure secondary to indicine N-oxide toxicity. A Pediatric Oncology Group Study. Cancer, 1983;52:61-3.

155. Miser JS, Smithson WA, Krivit W, Hughes $\mathrm{CH}$, Davis D, Krailo MD, Hammond GD. Phase II trial of indicine $\mathrm{N}$-oxide in relapsed acute leukemia of childhood. A report from the Children's Cancer Study Group. Am J Clin Oncol, 1992;15:135-40.

156. Bode AM, Dong Z: Toxic phytochemicals and their potential risks for human cancer. Cancer Prev Res (Phila). 2015;8(1):1-8. doi: 10.1158/19406207.CAPR-14-0160.

157.Roeder E, Wiedenfeld H: Plants containing pyrrolizidine alkaloids used in the traditional Indian medicine-including ayurveda. Pharmazie. 2013 ;68(2):83-92.

158.Zhou SF, Xue CC, Yu XQ, Wang G. Metabolic activation of herbal and dietary constituents and its clinical and toxicological implications: an update. Curr Drug Metab. 2007;8(6):526-53.

159. Roeder E, Wiedenfeld H, Edgar JA. Pyrrolizidine alkaloids in medicinal plants from North America. Pharmazie. 2015;70(6):357-67.

160.Röder E, Medicinal plants in Europe containing 
pyrrolizidine alkaloids, Pharmazie 1995; 50: 83-98.

161.Röder E, Analysis of pyrrolizidine alkaloids, Current Organic Chemistry 1999; 3: 667-676.

162.Röder E, Medicinal plants in China containing pyrrolizidine alkaloids, Pharmazie 2000; 55: 711726.

163. Complementary and Alternative Medicine in the United States. Institute of Medicine Committee on the Use of Complementary and Alternative Medicine by the American Public; National Academies Press (US), Washington (DC), 2005.

164.US Food and Drug Administration. Information for consumers: Dietary supplements. US Food and Drug Administration.

http:/www.fda.gov/Food/DietarySupplements/Cons umerInformation/default.htm (Accessed on July 10, 2012).

165.Federal Food, Drug, and Cosmetic Act (FD\&C) Act http:/www.fda.gov/RegulatoryInformation/Legislati on/FederalFoodDrugandCosmeticActF

DCAct/default.htm (Accessed on July 10, 2012).

166.US Food and Drug Administration. Center for Food Safety and Applied Nutrition. Dietary Supplements http://www.fda.gov/Food/DietarySupplements/defau lt.htm (Accessed on July 10, 2012).

167.US Food and Drug Administration. Claims that can be made for conventional foods and dietary supplements

http://www.fda.gov/Food/LabelingNutrition/LabelCl aims/ucm1 11447.htm (Accessed on July 10, 2012).

168.US Food and Drug Administration. Guidance, Compliance \& Regulatory Information http:/www.fda.gov/food/DietarySupplements/Guida nceComplianceRegulatoryInformation (Accessed on July 10, 2012).

169.FDA advises dietary supplement manufacturers to remove comfrey products from the market http:/www.fda.gov/Food/DietarySupplements/Alert s/ucm111219.htm (Accessed on December 14, 2011).

170. National policy on traditional medicine and regulation of herbal medicines: report of a WHO global survey. WHO. Geneva 2005. Available at: http://apps.who.int/medicinedocs/en/d/Js7916e/ (Accessed on April 23, 2012)

171.Bundesgesundheitsamt, Bekanntmachung uber die Zulassung und Registrierung von Arzneimitteln, Bundesanzeiger 1992. 111: 4805;

172.Kempf M, Reinhard A, Beuerle T. Pyrrolizidine alkaloids (PAs) in honey and pollen-legal regulation of PA levels in food and animal feed required. Mol Nutr Food Res. 2010;54(1):158-68. doi: 10.1002/mnfr.200900529.

173. Boppré $\mathrm{M}$. The ecological context of pyrrolizidine alkaloids in food, feed and forage: an overview. Food Addit Contam Part A Chem Anal Control Expo Risk
Assess.

2011;28(3):260-81.

doi:

10.1080/19440049.2011.555085.

174.Calixto JB: Efficacy, safety, quality control, marketing and regulatory guidelines for herbal medicines (phytotherapeutic agents). Braz J Med Biol Res. 2000;33(2):179-89.

175.Calapai G: European legislation on herbal medicines: a look into the future. Drug Saf. 2008;31(5):428-31.

176.UK Committee on Toxicity, http://cot.food.gov.uk/sites/default/files/cot/cotstate mentpa200806.pdf

177.European Food Safety Authority, http://www.efsa.europa.eu/sites/default/files/scientifi c_output/files/main_documents/2406.pdf

178.Bundesamt für Risiokobewertung (BfR) http://www.bfr.bund.de/cm/349/chemical-analysisand-toxicity-of-pyrrolizidine-alkaloids- andassessment-of-the-health-risks-posed-by-theiroccurence-in-honey.pdf

179. Dutch authority on herbal preparation, http://www.rivm.nl/dsresource?objectid=rivmp:2763 $09 \&$ type $=$ org\&disposition $=$ inline \&ns_nc $=1$

180.Codex Alimentarius Commission Review, $\mathrm{ftp} / / / \mathrm{ftp}$.fao.org/codex/meetings/cccf/cccf5/cf05_14e .pdf

181. Silano V, Coppens P, Larrañaga-Guetaria A, Minghetti P, Roth-Ehrang R. Regulations applicable to plant food supplements and related products in the European Union.Food Funct. 2011; 2(12):710-9.

182. Nicoletti M: Nutraceuticals and botanicals: overview and perspectives. Int J Food Sci Nutr. 2012;63 Suppl 1:2-6. doi: 10.3109/09637486.2011.628012.

183.Edgar JA , Colegate SM , Boppré M, \& Molyneux RM Pyrrolizidine alkaloids in food: a spectrum of potential health consequences, Food Additives \& Contaminants: 2011, 28:3, 308-324, DOI: 10.1080/19440049.2010.547520

184.Fu PP, Yang YC, Xia Q, Chou MW, Cui YY, Lin G. Pyrrolizidine Alkaloids - Tumorigenic Components in Chinese Herbal Medicines and Dietary Supplements Journal of Food and Drug Analysis, 2002,10,4, 198-211

185.Zhu L, Li N, Ruan, Fu PP, Zhao ZZ, Lin G. Chemical diversity investigation of hepatotoxic pyrrolizidine alkaloids in Qianliguang (Senecio scandens) and related species by UHPLC-QTOF-MS. World Journal of Traditional Chinese Medicine, 2015| Vol. 1| Issue 2, 1-11.

186.Medicines and Healthcare Products Regulatory Agency. MLX 296: proposals to prohibit the sale, supply or importation of unlicensed herbal medicinal products for internal use which contain Senecio species. Monograph on the Internet. Available at: http://www.mhra.gov.uk/Publications/Consultations/ Medicinesconsultations/MLXs/CON. 
Table 1.

\begin{tabular}{ccc}
\hline Species & Use-Toxicity & PA \\
\hline BORAGINACEAE FAMILY & \\
\hline
\end{tabular}

Alkanna tinctoria aka

Lithospermum

tinctorium

Alkannet

Amsinckia intermedia

Fiddleneck

Anchusa officinalisL.

Alkannet, bugloss

Borago officinalis $L$.

Borage

Cynoglossum officinale

hound's tongue, bugloss

Heliotropium arborescens $L$.

$H$ indicum $L$. Da wei yao

$H$. popovii, H. lasiocarpum; $H$. eichwaldii, $H$. bacciferum

Heliotrope

Lappula intermedia M.Popov

Stickseed

Lithospermum officinale

Gromwell

Lithospermum erythrorhizon

Zi cao

Myosotis scorpioidesL.

forget-me-not.

Symphytum officinale L,(comfrey)

S. asperum Lepech, S. caucasicum

Bieb.,

S. peregrinum

S. tuberosum,

S. uplandicum Nyman (Russian comfrey)

Trichodesma africana also: T. incanum
Triangularine

Skin diseases, diarrhea.

Horses and cows poisoned by it.

Skin ulcers, expectorant and diuretic

Diuretic, inflammatory diseases and cough

diarrhea; skin bruises.

Causes liver cancer

H. indicum: Ulcer, wounds, local inflammation

Livestock feed on heliotropium species -medicinal herb cause liver cancer; contaminated cereal crops cause human poisoning.

-topically for sores and swellings.

Intermedine

L. intermedia - Ascariasis, oxyuriasis, infantile malnutition

\section{Lithosenine}

Contraceptive, antipyretic, gout, kidney stones, diarrhea..

skin diseases, antipyretic, antiphlogistic,

produces tumors

Sedative, tonic; externally eye wash.

myoscorpine, scropioidine, symphytine

intermedine, lycopsamine, symphytine, echimidine, symglandine.

Causes liver damage in humans

Contaminated cereal crops cause human poisoning.

\section{ASTERACEA (COMPOSITAE) FAMILY}

Adenostyles alliariae Kern Lung disorders Causes HSOS

Lycopsamine, senecionine, seneciphylline, and spartioidine. 
Chinese medicine

Ageratum conyzoides L. Sheng hong ji

\section{Brachyglottis repens}

Chromolaena odorata Fei ji cao

Crassocephalum crepidioides Jia tong hao

Emilia sonchifolia DC red tasselflower, Emilia's flower, Yang ti cao, Yi dian hong

Eupatorium cannabinum L . Pei lan,

E. purpreum - Joe Pye Weed Eupatorium japonicum Thunb. Hua zhe lan

E. perforatum, boneset

E. rugosum

E. cannabinum hemp agrimony

E. fortunei (Pai Lan)-Chinese medicine

Farfugium japonicum Kitam Lian peng cao

Gynura bicolor DC Guan yin xian,

Gynura segetum Merr. Ju shan qi, Tu san chii

Ligularia hodgsonnii Hook

Lithospermum

erythrorhizon Zi Cao,

Petasites hybridus PH Gaertn., B., Mey \& Scherb. (Colts food), pestilence-wort or butterbur P. spurius. RCHB

Senecio argunensis Turcz. Yu yie qian li guang

S. aureus- golden ragwort;

S. abrotarifolius,

S.alpestre,

S. bohemicus,

S. bicolor Tod. ssp. cineraria,

Senecio chrysanthemoides DC

Chien li kuang,

S. douglasii

S. doronicum,

S. fluviatilis

S. fuchsii

S. Illiciformis

S. jacobaea L., tansy (European)
A. conyzoides $L$. Chinese medicine antipyretic, common colds, malaria

Crops are used for feeding animals. In horses, causes paralysis of the limbs.

Hemostatic; produces tumors C. crepidioides Cold, dysentery, urinary infection

Antipyretic influenza, cough, hemoptysis and bronchitis

E. cannabinum Influenza, cerebral stroke;

E. japonicum: Measles, rheumatic pains and colds

E. purpureum fever; diuretic, lowering cholesterol;

symptoms of summer-heat syndrome.

Colds and flu

Dysmenorrhea, tuberculous hymoptysis

Hemoptysis, peripheral blood

circulation disorder

Anti-tussive traditional Chinese medicine produced in rural areas of Sichuan providence

Causes abdominal pain

S.argunensis-Chinese medicine Antienteritis;

S. aureus Diaphoretic and diuretic; high doses may induce abortion.

S. bicolor has been used in eye drops to treat cataracts and conjunctivitis.

S. chrysanthemoides Chinese medicine, Traumatic injury, breast abscesses

Senecio sp. are used in Chinese medicine: febrile diseases, dysuria, inflammation, diarrhea, and, cataracts. Livestock - antispasmodic.

S. longilobus - causes liver failure; S. nemorensis (Chinese medicine) Enteritis, hepatitis, boils
Senecionine

Intermidine

Jacobine

senkirkine and doronine;

supinine, rinderine, echinatine, intermidine and lycopsamine.
Petasitenine, senkirkine

\section{Retrorsine}

Senecionine,seneciphylline

otonecine-type PA, clivorine and ligularine,

senecionine, integerrimine, retrosine, seneciphylline, jacobine, senkirkine

senecionine, riddelline, retrorsine, floridanine, monocrotaline, otosenine seneciphylline 
ragwort

S. longilobus

S. nemorensis L, Huana wan

S. scandens Qian Li Guang

S. sylvaticus,

S. tomentosus

S. vulgaris $L$.
Senecio is used in African herbal

medicine causes liver cancer.

Contaminated cereal crops- human

poisoning; causes infant death.

Qianliguang is traditional herbal medicine growing in different locations

of China. It is registered and sold as herbal remedy in western countries. It may lead to toxic adverse reactions. Quian li guang or Chiu li ming Oral and pharyngeal infection
Tussilago farfara $L$. Coltsfoot

Kuan Dong Hua (Chinese medicine). lung disorders (chronic bronchitis,

Senkirkine, senecionine

\section{FABACAEA FAMILY}

Crotalaria sp. rattlebox

C. assamica Benth $\mathrm{Zi}$ xiao rong (Nung gi li) Chinese remedy, C. mucronata Zhu zi tou Chinese medicine

C. juncea, C. nana, C. retusa, $C$. fulva; C. sessiliflora $L$ crotananine, monocrotaline cronaburmin, Antipyretic and diuretic Contaminated cereal crops blamed for human poisoning. retrorsine 